\title{
PENGARUH APLIKASI DISCORD DALAM PEMBELAJARAN DARING TERHADAP HASIL BELAJAR PADA MATAKULIAH KOMPUTER
}

\author{
M.Rasyid Ridho' ${ }^{1}$ Muhaimin ${ }^{2}$, Harry Soedarto Harjono ${ }^{3}$ \\ Mahasiswa Universitas Jambi ${ }^{1}$, Dosen Universitas Jambi ${ }^{2}$, \\ Dosen Universitas Jambi ${ }^{3}$ \\ Jalan Raden Mattaher No. 16 Jambi \\ Sur-el: mrasyidridho95@gmail.com¹, muhaimin.fkip@unja.ac.id ${ }^{2}$, \\ hary.soedarto@unja.ac.id ${ }^{3}$
}

Article info

Article history:

Received: 11-04-21

Revised : 26-04-21

Accepted: 30-05-21

Keywords:

Discord Application,

Student Learning

Outcomes and

Motivation

Kata Kunci:

Aplikasi Discord,

Hasil Belajar dan

Motivasi Belajar

Mahasiswa

\begin{abstract}
A B S T R A C T
This study aims to explain the influence of Discord application in online learning on student learning outcomes and motivation. Quantitative method with quasi-experimental design with 40 samples. Data collection uses tests and questionnaires, analysis data using instrument tests, normality, homogeneity, while hypothetical tests use Wilcoxon, Mann-Whiteney (U), and Spearman tests. The results of post-test experiment class obtained an average score 83.5 higher than control class 61.25. Based on Wilcoxon Test Asymp.Sig (2-tailed) obtained $0.000<0.05$, Hal received, Mann-Whiteney Test (U) High motivation obtained $U=1,500$ Asymp.Sig (2-tailed) obtained $0.000<$ 0.05 , Ha2 Low motivation obtained U=0.000 Asymp.Sig (2-tailed) obtained $0.000<0.05, \mathrm{Ha} 3$ received, there is a significant difference between the results of using discord application and using Whatsapp, Spearman Test Asymp.Sig (2-tailed) obtained $0.000<0.05$, Ha4 received, correlation coefficient value of $0.973 * *$ means the relationship between learning motivation variables and learning outcomes is very strong.
\end{abstract}

Penulisan ini bertujuan untuk menjelaskan pengaruh aplikasi Discord dalam pembelajaran daring terhadap hasil belajar dan motivasi belajar mahasiswa. Metode kuantitatif dengan desain quasi eksperimen dan sampel berjumlah 40. Pengumpulan data mengunakan test dan kuesioner, anilisis data menggunakan uji instrument, normalitas, homogenitas, Sedangkan uji hipotesis menggunakan Uji Wilcoxon, Mann-Whiteney (U), dan Spearman. Hasil penulisan post-test kelas eksperimen diperoleh nilai rata-rata 83.5 lebih tinggi dari kelas kontrol sebesar 61.25. Berdasarkan Uji Wilcoxon pada Asymp.Sig (2-tailed) didapatkan $0.000<0.05, H_{a l}$ diterima, Uji Mann-Whiteney (U) Motivasi tinggi diperoleh $U=1.500$ pada Asymp.Sig (2-tailed) didapatkan $0.000<0.05, \mathrm{H}_{a 2}$ Motivasi rendah diperoleh $U=0.000$ pada Asymp.Sig (2-tailed) didapatkan $0.000<0.05, H_{a 3}$ diterima, dikatakan ada perbedaan yang signifikan antara hasil belajar kelas yang menggunakan aplikasi Discord dengan menggunakan Whatsapp, Uji Spearman pada Asymp.Sig (2tailed) didapatkan $0.000<0.05, H_{a 4}$ diterima, nilai koefisien korelasi $0.973 * *$ artinya hubungan antara variabel motivasi belajar dengan hasil belajar sangat kuat.

Direktorat Riset dan Pengabdian Masyarakat Universitas Bina Darma. 


\section{JURNAL ILMIAH \\ BINA EDUKASI \\ ISSN 1979-8598 E-ISSN: 2655-8378 \\ http://journal.binadarma.ac.id/index.php/jurnalbinaedukasi \\ Vol. 14, No. 1, Juni 2021, 22 - 35}

\section{PENDAHULUAN}

Proses pembelajaran dalam jaringan (daring) merupakan sebuah tuntutan sebagai solusi untuk menyesuaikan dengan situasi dan kondisi saat ini, dan siap tidak siap harus berlangsung. Bagi sebagian dosen proses pembelajaran daring merupakan suatu hal yang baru dan belum terbiasa. Fenomena pembelajaran daring saat ini membuat kesulitan bagi dosen. Setiap dosen saat ini dipaksa untuk menggunakan perangkat yang ada guna mendukung pendidikan secara daring.

Pemilihan media yang tepat dalam pembelajaran selama masa pendemi ini bertujuan untuk menghasilkan output yang baik dan disesuaikan dengan kebutuhan dan kondisi yang ada. Pembelajaran secara daring yang menjadi tuntutan saat ini dapat menggunakan media daring. Tantangan bagi dosen pada masa pandemi ini adalah bagaimana mengupayakan proses pembelajaran dengan media daring dapat optimal dan tidak mengurangi esensi yang akan disampaikan oleh pendidik kepada mahasiswa seperti pembelajaran tatap muka.

Penerapan Information Technology (IT) di bidang pendidikan ini tidak serta merta lancar, beragam kendala yang dihadapi (Absor, 2020). Dalam upaya mengatasi kendala-kendala yang ditemui, maka digunakanlah berbagai aplikasi yang sesuai untuk mengatasi kendala yang dihadapi agar pembelajaran dapat berjalan dengan baik. Menyikapi Surat edaran dari pemerintah, universitas Tridinanti Palembang juga melaksakan sistem pelayanan dan pembelajaran daring, mahasiswa tetap dapat mengikuti perkulihan seperti biasa tetapi dengan menggunakan aplikasiaplikasi yang dapat mendukung pembelajaran daring berdasarkan arahan dari dosen pengampu mata kuliah, seperti aplikasi; WhatsApp, zoom cloud meeting dan google classroom. Namun faktanya masih banyak dosen yang kesulitan menggunakan aplikasi pembelajaran yang sulit dipahami dalam waktu singkat sehinga mereka masih membagikan materi dan tugas kepada mahasiswa seadanya, efektifitas waktu yang sangat kurang, kesempatan berinteraksi dalam menjelaskan materi sangat kurang sehingga kurang menarik dan membosankan dalam proses pembelajaran daring tersebut, informasi ini penulis dapatkan dari dosen yang mengajar di Universitas Tridinanti Palembang pada Agustus 2020.

Berdasarkan wawancara yang telah dilakukan, penulis ingin memperkenalkan aplikasi Discord sebagai alternatif untuk pembelajaran daring yang mudah dipahami dan digunakan. Discord belakang menjadi salah satu aplikasi yang mulai digunakan dalam pembelajaran daring. Discord merupakan aplikasi yang sudah sangat popular dilingkungan mahasiswa khususnya mahasiswa yang sering bermain game online, untuk berkomunikasi antar pemain dalam satu tim atau komunitas.

Discord adalah aplikasi gratis untuk mengakses obrolan yang mirip dengan aplikasi Slack atau Skype yang memungkinkan pengguna untuk mengobrol secara real time menggunakan teks, suara atau video. Awalnya Discord dibuat untuk video gamer untuk berinteraksi satu sama 


\section{JURNAL ILMIAH \\ BINA EDUKASI \\ ISSN 1979-8598 E-ISSN: 2655-8378 \\ http://journal.binadarma.ac.id/index.php/jurnalbinaedukasi \\ Vol. 14, No. 1, Juni 2021, 22 - 35}

lain saat bermain game (Raihan, 2018), dan saat ini Discord semakin populer dengan lebih dari 100 juta pengguna. Discord dapat digunakan dalam sistem berbasis windows, iOS, Android, Linux, bahkan Mac. Aplikasi Discord memiliki berbagai fasilitas untuk berkomunikasi yang tidak dimiliki oleh aplikasi lain. Salah satunya fitur untuk berkomunikasi layaknya telepon. Fitur ini memungkinkan dosen untuk menyampaikan materi secara leluasa kepada mahasiswa.

Penggunaan aplikasi Discord sebagai media juga dilakukan oleh Kusnedi (2020), Implementasi Problem Based Learning berbantuan aplikasi Discord dan Media Flipbook pada mata pelajaran Komputer dan Jaringan Dasar Materi Sistem Operasi dapat meningkakan hasil belajar siswa kelas X TKJ. Hal ini dapat lihat dari perolehan nilai rata-rata hasil evaluasi pada siklus I dan siklus II sebelum menggunakan media pembelajaran Flipbook adalah 69,09 dan 74,54. Sedangkan nilai rata-rata hasil evaluasi pada siklus III sesudah menggunakan media pembelajaran Flipbook adalah 82,42. Persentase ketuntasan hasil belajar siswa pada siklus I dan siklus II sebelum menggunakan media pembelajaran Flipbook adalah 45,45\% dan 60,60\%. Sedangkan pada siklus III persentase ketuntasan hasil belajar siswa adalah 84,84\%.

Selanjutnya Wulanjani, (2018), untuk kesesuaian terdapat 30 dari 31 siswa atau 97\% siswa yang menyatakan bahwa Discord layak digunakan pada kelas virtual listening. Penggunaan Discord sangat mudah dibuktikan dengan respon siswa pada soal nomor 2. Dari 31 siswa terdapat 30 yang berpendapat bahwa Discord mudah diterapkan selama kelas virtual listening. Artinya hanya 1 dari mereka yang mengalami kesulitan dalam menerapkan Discord. Untuk pertanyaan nomor 4, terdapat 29 siswa atau 94\% siswa menyatakan bahwa Discord dapat membantu mereka selama kelas mendengarkan virtual. Sebagian besar siswa menikmati dan antusias mengikuti kelas virtual listening dengan menggunakan Discord.

Kemudian Efriani dkk (2020) juga dalam penulisan dengan judul "Pemanfaatan Aplikasi Discord Sebagai Media Pembelajaran ONLINE” Discord menyediakan kemudahan dalam pembelajaran, diantaranya: (1) pembelajaran tidak terikat oleh ruang kelas, (2) dapat digunakan untuk mata kuliah / mata pelajaran yang sama untuk 2 atau lebih kelas yang berbeda, (3) menyediakan fitur-fitur yang mendorong terjadinya interaksi dan komunikasi di antara para peserta (members) (4) memungkinkan pembelajaran memiliki lebih dari 2 dosen atau ahli, (5) interaksi dapat dilakukan dengan Text chanel dan voice chanel.

Pembelajaran dengan media daring yang dilaksanakan secara optimal dengan harapan output yang dihasilkan juga akan maksimal, tidak menimbulkan kejenuhan, kebosanan baik dari dosen maupun mahasiswa, sehingga dalam kondisi belajar dari rumah tetap akan mencetak generasi yang unggul. Memberikan sumbangsi pada ilmu pengetahuan tentang penggunaan aplikasi Discord dalam pembelajaran Daring sebagai media pembelajaran yang tepat, efektif, inovatif dan dapat digunakan dalam pembelajaran, serta dapat meningkatkan hasil belajar mahasiswa. 


\section{JURNAL ILMIAH \\ BINA EDUKASI \\ ISSN 1979-8598 E-ISSN: 2655-8378 \\ http://journal.binadarma.ac.id/index.php/jurnalbinaedukasi \\ Vol. 14, No. 1, Juni 2021, 22 - 35}

Manfaat praktis bagi dosen; membantu dosen dalam melaksanakan pembelajaran secara individual, interaktif, dan kreatif dengan sumber belajar yang luas (open source), dapat memfasilitasi pengembangan potensi, gaya belajar, serta kebutuhan belajar mahasiswa yang beragam, termotivasi untuk mengembangkan E-Learning, dan dapat berperan sebagai fasilitator dalam pembelajaran. Bagi mahasiswa; mahasiswa dapat melakukan pembelajaran di mana pun dan kapan pun jika E-Learning ini dimanfaatkan secara optimal, mahasiswa dapat belajar menurut kemampuan dan minatnya, dan mahasiswa memiliki sumber belajar yang luas. Bagi institusi; dapat dijadikan program sebagai media pengajaran daring, sehingga lebih mudah mengkoordinasi proses belajar mengajar.

\section{METODOLOGI PENELITIAN}

\subsection{Pengenalan Aplikasi Discord}

Dikutip dari Citron (2020), Discord adalah sebuah aplikasi pengirim pesan instan gratis dengan fitur VoIP, obrolan video dan fitur untuk mendukung permainan video seperti integrasi dengan Twitch.tv dan Steam. Discord ditujukan terutama untuk pemain, pembuat konten, pengembang, dan penjual permainan video. Discord digunakan oleh sekitar 56 juta pemain permainan video tiap bulannya karena adanya fitur yang mendukung permainan video. Discord dapat berjalan pada peramban web dan aplikasinya sendiri.

Discord adalah aplikasi gratis untuk mengakses obrolan yang mirip dengan Slack atau Skype yang memungkinkan pengguna untuk mengobrol secara real time menggunakan teks, suara atau video. Awalnya dibuat untuk video gamer untuk berinteraksi satu sama lain saat bermain game. Discord saat ini semakin populer dengan lebih dari 100 juta pengguna saat ini. Aplikasi ini menampung server atau ruang obrolan tentang berbagai topik, mulai dari game, musik, anime, dan meme cenderung menjadi yang paling populer.

Discord dapat diakses melalui komputer desktop, browser, atau dengan aplikasi seluler. Pengguna dapat mengatur atau bergabung dengan ruang obrolan, yang disebut Discord sebagai 'Server'. Pengguna dapat bergabung dengan grup yang telah diundang ke mereka atau membuat server obrolan pribadi mereka sendiri dan mengundang teman-teman mereka, kemudian dapat menggunakan teks, atau suara untuk mengobrol, dengan orang lain menggunakan server atau ruang obrolan itu. Ada juga server publik yang bisa diikuti siapa saja.

\subsection{Manfaat dan Kegunaan Aplikasi Discord}

Ada beberapa fungsi dan keunggulan yang bisa didapatkan dari aplikasi Discord dalam pemanfaatannya sebagai Learning Management System (LMS), sebagai berikut. 


\section{JURNAL ILMIAH \\ BINA EDUKASI \\ ISSN 1979-8598 E-ISSN: 2655-8378 \\ http://journal.binadarma.ac.id/index.php/jurnalbinaedukasi \\ Vol. 14, No. 1, Juni 2021, 22 - 35}

\subsubsection{Proses setting pembuatan kelas yang cepat dan nyaman}

Proses pembuatan kelas pada Discord sangat cepat dan nyaman jika dibandingkan harus menginstall LMS lokal atau mendaftarkan ke provider LMS. Dosen hanya tinggal mengakses aplikasi Discord bisa menggunakan aplikasi pada PC/laptop atau via browser dan bisa diakses menggunakan handphone/smartphone.

Setelah membuat akun pada Discord, maka dosen sudah bisa mulai melakukan pengelolaan kelas. Interface Discord juga sederhana dan mudah untuk digunakan (user friendly), sehingga akan ideal digunakan bagi setiap pengajar dengan tingkat pengalaman E-Learning yang beragam.

\subsubsection{Hemat dan efisiensi waktu}

Dosen bisa mendistribusikan bahan ajar, media pembelajaran, dan LKPD untuk mahasiswa secara daring pada Discord. Semuanya dilakukan secara paperless (bebas kertas), sehingga tidak ada waktu yang terbuang untuk mendistribusikan dokumen fisik dan siswa dapat menyelesaikan tugas mereka dengan cepat secara online, sehingga lebih mudah bagi mereka untuk memenuhi deadline waktu yang diberikan dan belajar secara online dapat disesuaikan dengan jadwal sehari-hari mereka. Dengan demikian, ada potensi untuk penghematan waktu dari kedua belah pihak baik siswa maupun dosennya.

\subsubsection{Mampu meningkatkan kerja sama dan komunikasi}

Salah satu manfaat paling penting dari menggunakan Discord sebagai e-learning sistem adalah kolaborasi online yang efisien. Dosen dapat mengirimkan pemberitahuan ke mahasiswa atau mahasiswa mereka untuk memulai pembelajaran secara daring pada kelas virtual yang sudah dibuat, ketika dosen memposting maka pada Handphone/Smartphone siswa akan muncul pesan atau notifikasi tentang apa yang dosen posting pada kelas Discord sehingga, mahasiswa bisa langsung mengetahui bahwa ada postingan baru dari dosen untuk kegiatan pembelajaran, diskusi online atau memberitahu mereka tentang kegiatan pembelajaran online tertentu.

Disisi lain, mahasiswa memiliki kesempatan untuk memberikan umpan balik kepada rekan-rekan mereka dan kepada dosen dengan mengunggah postingan langsung ke dalam diskusi di Discord.

\subsection{Hipotesis Penulisan}

Sugiyono (2016), mengatakan bahwa hipotesis merupakan jawaban sementara terhadap rumusan masalah penulisan, dimana rumusan masalah penulisan telah dinyatakan dalam bentuk kalimat pertanyaan. Dikatakan sementara, karena jawaban yang diberikan baru didasarkan pada teori yang relevan, belum didasarkan pada fakta-fakta empiris yang diperoleh melalui pengumpulan data. Hipotesis dari permasalahan di atas adalah sebagai berikut:

$\mathrm{H}_{01}$ : Tidak terdapat pengaruh hasil belajar mahasiswa sebelum dan sesudah yang diajarkan menggunakan Aplikasi Discord 


\section{JURNAL ILMIAH \\ BINA EDUKASI \\ ISSN 1979-8598 E-ISSN: 2655-8378 \\ http://journal.binadarma.ac.id/index.php/jurnalbinaedukasi \\ Vol. 14, No. 1, Juni 2021, 22 - 35}

$\mathrm{Ha}_{1}$ : Terdapat pengaruh hasil belajar mahasiswa sebelum dan sesudah yang diajarkan menggunakan Aplikasi Discord

$\mathrm{H}_{02}$ : Tidak terdapat pengaruh hasil belajar mahasiswa yang memiliki motivasi belajar tinggi yang diajarkan dengan menggunakan Aplikasi Discord dan diajarkan dengan menggunakan Aplikasi Whatsapp.

$\mathrm{Ha}_{2}$ : Terdapat pengaruh hasil belajar mahasiswa yang memiliki motivasi belajar tinggi yang diajarkan dengan menggunakan Aplikasi Discord dan diajarkan dengan menggunakan Aplikasi Whatsapp.

$\mathrm{H}_{03}$ : Terdapat pengaruh hasil belajar mahasiswa yang memiliki motivasi belajar rendah yang diajarkan dengan menggunakan Aplikasi Discord dan diajarkan dengan menggunakan Aplikasi Whatsapp.

$\mathrm{H}_{\mathrm{a} 3}$ : Terdapat pengaruh hasil belajar mahasiswa yang memiliki motivasi belajar rendah yang diajarkan dengan menggunakan Aplikasi Discord dan diajarkan dengan menggunakan Aplikasi Whatsapp.

$\mathrm{H}_{04}$ : Tidak terdapat hubungan antara motivasi belajar dan hasil belajar mahasiswa pada penggunaan Aplikasi Discord

$\mathrm{H}_{\mathrm{a} 4}$ : Terdapat hubungan antara motivasi belajar dan hasil belajar mahasiswa pada penggunaan Aplikasi Discord

\subsection{Metode Penulisan}

Penulis menggunakan metode Kuantitatif, Creswell (2012), mendefinisikan, penulisan kuantitatif mengharuskan penulis untuk menjelaskan bagaimana variabel memengaruhi variabel yang lain. Penulisan ini termasuk jenis penulisan eksperimen. Menurut Creswell (2012) penulisan eksperimen merupakan penulisan untuk menguji suatu ide, praktek atau prosedur untuk menentukan apakah mempengaruhi hasil atau variabel dependen. Penulis mengontrol semua variabel yang mempengaruhi hasil kecuali untuk variabel independen. Kemudian, ketika variabel independen mempengaruhi variabel dependen, kita dapat mengatakan variabel independen "penyebab" atau "mungkin disebabkan" variabel dependen.

Dalam penulisan ini, penulis menggunakan non randomized pre-test post test control group design. Pada awal penulisan, penulis akan memberikan pre-test untuk kedua kelompok, untuk kelompok eksperimental diberikan peralakuan sementara, kelompok kontrol tidak diberikan perlakuan dan kemudian, pada akhir penulisan, penulis akan memberikan post-tes bagi kedua kelompok untuk menilai peningkatan antara kedua kelompok. Berdasarkan Sugiyono (2016), rancangan eksperimen yang digunakan dalam penulisan ini adalah menggunakan non randomized pre-test post-test control group design, rancangan ini dipilih karena selama eksperimen tidak memungkinkan untuk mengubah kelas yang telah ada. Dapat disajikan melalui tabel berikut. 
ISSN 1979-8598 E-ISSN: 2655-8378

http://journal.binadarma.ac.id/index.php/jurnalbinaedukasi

Vol. 14, No. 1, Juni 2021, 22 - 35

Tabel 1. Rancangan Eksperimen

\begin{tabular}{lccc}
\hline Kelompok & Pre-test & Treatment & Post-test \\
\hline Eksperimen & $\mathrm{O} 1$ & $\mathrm{X}$ & $\mathrm{O} 2$ \\
\hline Kontrol & $\mathrm{O} 3$ & - & $\mathrm{O} 4$ \\
\hline Sumber: Sugiyono (2016:79) Non Equivalent control group design
\end{tabular}

\section{Keterangan:}

O1 : $\quad$ Pre-test pada Kelas Eksperimental

O2 : $\quad$ Post-test pada Kelas Eksperimental

O3 : $\quad$ Pre-test pada Kelas Kontrol

O4: $\quad$ Post-test pada Kelas Kontrol

X : $\quad$ Treatment pada Kelas Eksperimental yang diajar menggunakan Aplikasi

Discord

\subsection{Teknik Pengumpulan Data}

Data yang diperoleh dalam penulisan ini adalah dari data hasil tes mengenai materi perangkat lunak pembuat presentasi Microsoft Office PowePoint. Tes merupakan salah satu cara untuk mengetahui bagaimana hasil belajar mahasiswa pada matakuliah Komputer dan juga dari hasil tes akan menggambarkan keberhasilan mahasiswa dalam proses pembelajaran.

\subsection{Teknik Analisis Data}

Data yang didapatkan dari hasil pre-test dan post-test selanjutnya dianalisis menggunakan aplikasi statistik SPSS 23.0. Adapun pengujian tersebut berupa Uji Hipotesis menggunakan Uji Wilcoxon, Uji Mann-Whiteney U, dan Uji Spearman.

\subsubsection{Uji Normalitas}

Tes normalitas yang digunakan untuk mengukur apakah data di kelas eksperimental dan kelas kontrol biasanya didistribusikan atau tidak (Budiyono, 2004). Dalam penulisan ini, penulis menggunakan komputasi statistik menggunakan IBM SPSS 23.0 untuk normalitas tes. Penulis mengukur data yang digunakan untuk menguji normalitas data. Jika probabilitas lebih tinggi dari 0.05, itu berarti bahwa data itu normal. Tes normalitas yang digunakan adalah Kolmogorov Smirnov.

\subsubsection{Uji Homogenitas}

Homogenitas varians adalah asumsi bahwa penyebaran skor kira-kira sama dalam kelompok kasus yang berbeda, atau lebih umum bahwa penyebaran skor kira-kira sama pada titik yang berbeda pada variabel prediktor. Jika probabilitasnya adalah 0.05 , itu berarti bahwa data memiliki beberapa varians, (Field, 2009). Penulis mengukur homogenitas pre-tes dan post-tes untuk kontrol dan kelompok eksperimental. 


\section{JURNAL ILMIAH \\ BINA EDUKASI \\ ISSN 1979-8598 E-ISSN: 2655-8378 \\ http://journal.binadarma.ac.id/index.php/jurnalbinaedukasi \\ Vol. 14, No. 1, Juni 2021, 22 - 35}

\subsubsection{Pengujian Hipotesis}

Metode statistik nonparametrik ini sering juga disebut metode bebas sebaran karena model uji statistiknya tidak menetapkan syarat-syarat tertentu tentang bentuk distribusi parameter populasinya. Untuk menguji taraf signifikan penulis menggunakan Uji Wilcoxon melihat kesignifikansian perbandingan dua sampel yang saling berhubungan (Sundayana, 2014). Ketentuan yang digunakan untuk menerima hipotesis adalah sebagai berikut: 1) Jika nilai signifikansi menunjukkan $\leq 5 \%$ hipotesis dapat diterima. 2) Jika nilai signifikansi menunjukkan $>5 \%$ hipotesis ditolak.

Untuk membandingkan hasil belajar mahasiswa yang memiliki motivasi belajar tinggi dan motivasi belajar rendah dengan menggunakan Aplikasi Discord dan penugasan berbantu Whatsapp, penulis menggunakan uji Mann-Whitney (U), Menurut McKnight, P. E., \& Najab, J. (2010), Uji Mann-Whitney U secara konseptual mirip dengan t-test untuk menentukan apakah dua kelompok sampel berasal dari populasi tunggal. Ketika data tidak memenuhi parametric asumsi uji-t, Mann-Whitney U cenderung lebih tepat, uji ini tergolong kuat sebagai pengganti ujit. Sebagai kriteria uji t-hitung berlaku ketentuan bila $t_{\text {tabel }} \leq \mathrm{t}_{\text {hitung }} \leq+\mathrm{t}_{\text {tabel }}$ maka Ho ditolak dan bila $\mathrm{t}_{\text {table }} \leq \mathrm{t}_{\text {hitung }} \geq+\mathrm{t}_{\text {tabel. }}$. dengan taraf signifikan $>0.05$ maka Ha, diterima.

Selanjutnya untuk melihat hubungan antar variabel dengan menggunakan Uji Spearman pada program SPSS 23.0. Menurut Sarwono dan Suhayati (2010), korelasi rank spearman digunakan untuk mengetahui hubungan atau pengaruh antara dua variabel berskala ordinal, yaitu variabel bebas dan variabel tergantung.

Setelah melalui perhitungan persamaan analisis korelasi rank spearman, kemudian dilakukan pengujian dengan menggunakan kriteria yang ditetapkan, yaitu dengan membandingkan nilai $\rho$ hitung dengan $\rho$ tabel. $\alpha 0,05$, yang dirumuskan sebagai berikut : Jika, $\rho$ hitung $\leq 0$, berarti Ho diterima dan Ha ditolak. Jika, $\rho$ hitung $>0$, berarti Ho ditolak dan Ha diterima.

\section{HASIL PENELITIAN DAN PEMBAHASAN}

\subsection{Hasil Penelitian}

\subsubsection{Uji Normalitas}

Tujuan uji normalitas adalah untuk bisa melihat apakah sampel berdistribusi normal atau tidak. Uji normalitas dilakukan sebelum mengolah data dengan uji Kolmogorov-Smirnov dengan bantuan SPSS 23.0, dengan kriteria output; Jika $\mathrm{H}_{0}$ : Distribusi populasi normal, jika probabilitas $>0.05, \mathrm{H}_{0}$ diterima. Jika $\mathrm{H}_{1}$ : Distribusi populasi tidak normal, jika probabilitas $\leq 0.05 \mathrm{H}_{0}$ ditolak. 
ISSN 1979-8598 E-ISSN: 2655-8378

http://journal.binadarma.ac.id/index.php/jurnalbinaedukasi

Vol. 14, No. 1, Juni 2021, $22-35$

Tabel 2. Uji Normalitas Kolmogorov-smirnov

\begin{tabular}{|c|c|c|c|c|c|c|c|}
\hline & & $\begin{array}{c}\text { Pre-Test } \\
\text { Eksperimen }\end{array}$ & $\begin{array}{c}\text { Post-Test } \\
\text { Eksperimen }\end{array}$ & $\begin{array}{l}\text { Pre-Test } \\
\text { Kontrol }\end{array}$ & $\begin{array}{c}\text { Post-Test } \\
\text { Kontrol }\end{array}$ & $\begin{array}{c}\text { Motivas } \\
\text { Eksperimen }\end{array}$ & $\begin{array}{l}\text { Motivasi } \\
\text { Kontrol }\end{array}$ \\
\hline $\mathrm{N}$ & & 20 & 20 & 20 & 20 & 20 & 20 \\
\hline \multirow{2}{*}{$\begin{array}{l}\text { Normal } \\
\text { Parameters }\end{array}$} & Mean & 51.50 & 83.50 & 48.50 & 61.25 & 78.00 & 73.25 \\
\hline & $\begin{array}{l}\text { Std. } \\
\text { Deviation }\end{array}$ & 13.485 & 7.273 & 10.650 & 9.014 & 9.646 & 5.637 \\
\hline \multirow{3}{*}{$\begin{array}{l}\text { Most Extreme } \\
\text { Differences }\end{array}$} & Absolute & .142 & .235 & .179 & .161 & .225 & .174 \\
\hline & Positive & .094 & .235 & .109 & .116 & .225 & .174 \\
\hline & Negative & -.142 & -.164 & -.179 & -.161 & -.222 & -.126 \\
\hline \multicolumn{2}{|l|}{ Test Statistic } & .142 & .235 & .179 & .161 & .225 & .174 \\
\hline \multicolumn{2}{|c|}{ Asymp. Sig. (2-tailed) } & $.200^{\mathrm{c}, \mathrm{d}}$ & $.005^{\mathrm{c}}$ & $.092^{\mathrm{c}}$ & $.184^{\mathrm{c}}$ & $.009^{\mathrm{c}}$ & $.114^{\mathrm{c}}$ \\
\hline
\end{tabular}

Seperti yang telah dijelaskan sebelumnya bahwa pada penulisan ini pelaksanaan test dilakukan sebanyak dua kali yakni: Pre-test-Post-test, sehingga untuk melakukan perhitungan normalitas dilakukan sebanyak empat kali. Berdasarkan perhitungan pengujian yang dilakukan dengan Uji Kolmogorov-Smirnov dengan bantuan aplikasi SPSS 23.0 terhadap hasil belajar Pretest kelas kontrol sebelum diberikan perlakuan didapatkan output: Test Kolmogorov-Smirnov pada baris Asymp. Sig. (2-tailed) sebesar 0.092 atau dapat ditulis sebagai probabilitas (p-value) $=0.092>0.05$ atau $\mathrm{H}_{\mathrm{a}}$ diterima. Dari data tersebut dapat disimpulkan bahwa hasil belajar Pre-test kelas kontrol sebelum diberikan perlakuan berdistribusi normal.

Sedangkan pengujian Kolmogorov-Smirnov dengan bantuan aplikasi SPSS 23.0 terhadap hasil belajar Pre-test kelas eksperimen sebelum diberikan perlakuan didapatkan output: Pada baris Asypm. Sig. (2-tailed) sebesar 0.200 atau dapat ditulis sebagai probabilitas (p-value) $=0.200>0.05$ atau $\mathrm{H}_{\mathrm{a}}$ diterima. Dari data tersebut dapat disimpulkan bahwa hasil belajar Pre-test kelas eksperimen sebelum diberikan perlakuan berdistribusi normal.

Sama seperti Pre-test, pada Post-test juga dilakukan uji normalitas untuk mengetahui apakah data berdistribusi normal atau tidak. Berdasarkan perhitungan pengujian yang dilakukan dengan Uji Kolmogorov-Smirnov dengan bantuan aplikasi SPSS 23.0 terhadap hasil belajar Posttest kelas kontrol setelah diberikan perlakuan didapatkan output: Pada baris Asymp. Sig. (2-tailed) sebesar 0.184 atau dapat ditulis sebagai probabilitas ( $\mathrm{p}$-value) $=0.184>0.05$ atau $\mathrm{H}_{\mathrm{a}}$ diterima Dari data tersebut dapat disimpulkan bahwa hasil belajar Post-test kelas kontrol yang menggunakan media penugasan Whatsapp berdistribusi normal.

Sedangkan pengujian Kolmogorov-Smirnov dengan bantuan aplikasi SPSS 23.0 terhadap hasil belajar Post-test kelas eksperimen diberikan perlakuan dengan Aplikasi Discord didapatkan output: Pada baris Asymp. Sig. (2-tailed) sebesar 0.005 atau dapat ditulis sebagai probabilitas $(\mathrm{p}$-value $)=0.005<0.05$ atau $\mathrm{H}_{0}$ diterima. Dari data tersebut dapat disimpulkan bahwa hasil belajar Post-test kelas eksperimen setelah diberikan perlakuan dengan Aplikasi Discord berdistribusi tidak normal. 


\section{JURNAL ILMIAH \\ BINA EDUKASI \\ ISSN 1979-8598 E-ISSN: 2655-8378 \\ http://journal.binadarma.ac.id/index.php/jurnalbinaedukasi \\ Vol. 14, No. 1, Juni 2021, 22 - 35}

\subsubsection{Uji Homogenitas}

Pengujian homogenitas dilakukan untuk mengetahui apakah data berasal dari populasi yang varians sama atau tidak. Pengujian homogenitas yang digunakan adalah uji one-way ANOVA Dengan hipotesis kriteria pengujian jika nilai Sig (2-tailed) $<0,05$ maka Ho ditolak, jik:a nilai Sig. (2-tailed) > 0,05 maka Ha diterima. Hasil pengujian dapat dilihat pada tabel berikut.

Tabel 3. Test Of Homogeneity of Variances

\begin{tabular}{lrrrrr}
\hline & Levene Statistic & df1 & df2 & Sig. \\
\hline Motivasi Belajar & 16.777 & 1 & 38 & .000 \\
Data Pre-Test & 1.333 & 1 & 38 & .256 \\
Data Post-Test & .445 & 1 & 38 & .509 \\
\hline
\end{tabular}

\section{Kriteria pengujian:}

1. Jika nilai Sig. (2-tailed) < (0.05) maka dapat menolak hipotesis Ho

2. Jika nilai Sig. (2-tailed) > (0.05) maka dapat menerima hipotesis Ha;

Dari hasil tabel output diatas dapat diketahui bahwa nilai signifikan Motivasi Belajar adalah 0.000 yang berarti > 0.05, maka dapat disimpulkan bahwa kelompok data mempunyai varian tidak sama atau tidak homogen, kemudian nilai signifikan Data Pre-Test adalah 0.256 yang berarti > 0.05, maka.dapat disimpulkan bahwa kelompok data mempunyai varian sama atau homogen, dan terakhir nilai signifikan data post-test adalah 0.509 yang berarti $>0.05$, maka.dapat disimpulkan bahwa kelompok data mempunyai varian sama atau homogen.

\subsubsection{Uji Hipotesis}

\subsubsection{Uji Wilcoxon}

Pengujian menggunakan Uji Wilcoxon dengan kriteria 1) Jika nilai signifikansi menunjukkan $\leq 5 \%$ hipotesis dapat diterima, 2) Jika nilai signifikansi menunjukkan > 5\% hipotesis ditolak. Dari hasil perhitungan pada Pre-test dengan menggunakan Uji Wilcoxon berbantuan Aplikasi SPSS 23.0 sebelum dan sesudah diberikan perlakuan didapatkan output.

Tabel 4. Hasil Uji Wilcoxon

Test Statistics ${ }^{\mathrm{a}}$

\begin{tabular}{lr}
\hline & Nilai Post-Test - Nilai Pre-Test \\
\hline $\mathrm{Z}$ & $-3.947^{\mathrm{b}}$ \\
Asymp. Sig. (2-tailed) & .000 \\
\hline
\end{tabular}

Pada test statistics, baris Asymp.Sig. (2-tailed) diperoleh nilai $=0.000<0,05$ maka dapat disimpulkan bahwa $\mathrm{H}_{\mathrm{a}}$ diterima. Dengan demikian dapat dikatakan bahwa ada perbedaan yang signifikan antara hasil belajar pre-test dan post-test. Dikarenakan ada perbedaan yang signifikan maka dapat menjawab hipotesis penulisan yaitu terdapat pengaruh hasil belajar mahasiswa sebelum dan sesudah yang diajarkan menggunakan aplikasi Discord. 


\section{JURNAL ILMIAH \\ BINA EDUKASI \\ ISSN 1979-8598 E-ISSN: 2655-8378 \\ http://journal.binadarma.ac.id/index.php/jurnalbinaedukasi \\ Vol. 14, No. 1, Juni 2021, 22 - 35}

\subsubsection{Uji Mann-Whitney}

Pengujian menggunakan Uji Mann-Whitney U menggunakan aplikasi SPSS 23.0 untuk mengetahui apakah terdapat perbedaan yang signifikan untuk nilai kedua kelompok.

1. Jika nilai Signifikansi atau Asymp. Sig. (2-tailed) $>0.05 \mathrm{H}_{0}$ diterima.

2. Jika nilai Signifikansi atau Asymp. Sig. (2-tailed) $<0.05 \mathrm{H}_{0}$ ditolak.

Dari hasil perhitungan dengan menggunakan Uji Mann-Whitney berbantuan Aplikasi SPSS 23.0 didapatkan output:

Tabel 5. Hasil Uji Mann-Whitney Motivasi Belajar Tinggi

\begin{tabular}{lr}
\multicolumn{2}{c}{ Test Statistics $^{\mathbf{a}}$} \\
\hline \multicolumn{2}{c}{ Hasil Belajar $^{2}$} \\
\hline Mann-Whitney U & 1.500 \\
Wilcoxon W & 67.500 \\
Z & -4.012 \\
Asymp. Sig. (2-tailed) & .000 \\
Exact Sig. [2*(1-tailed Sig.)] & $.000^{\mathrm{b}}$ \\
\hline
\end{tabular}

Pada Test Statistics, baris Mann-Whitney $U$ diperoleh harga $U=1.500$ dan baris Asymp.Sig. (2-tailed) diperoleh nilai $=0.000<0,05$ maka dapat disimpulkan bahwa $\mathrm{H}_{\mathrm{a}}$ diterima. Dengan demikian dapat dikatakan bahwa ada perbedaan hasil belajar dengan motivasi tinggi antara kelas ekperimen dan kelas kontrol. Dikarenakan perbedaan yang signifikan maka dapat menjawab hipotesis penulisan yaitu terdapat pengaruh hasil belajar mahasiswa yang memiliki motivasi belajar tinggi yang diajarkan dengan menggunakan aplikasi Discord dan diajarkan dengan menggunakan aplikasi Whatsapp. Kemudian untuk menjawab hipotesis penulisan ke tiga yang membandingkan hasil belajar yang dilihat dari motivasi belajar rendah, yaitu dari hasil perhitungan dengan menggunakan Uji Mann-Whitney berbantuan aplikasi SPSS 23.0 didapatkan output:

Tabel 6. Hasil Uji Mann-Whitney Motivasi Belajar Rendah

\begin{tabular}{lr}
\multicolumn{2}{c}{ Test Statistics $^{\mathbf{a}}$} \\
\hline \multicolumn{2}{c}{ Hasil Belajar $^{2}$} \\
\hline Mann-Whitney U & .000 \\
Wilcoxon W & 45.000 \\
Z & -3.483 \\
Asymp. Sig. (2-tailed) & .000 \\
Exact Sig. [2*(1-tailed Sig.)] & $.000^{\mathrm{b}}$ \\
\hline
\end{tabular}

Pada test statistics, baris Mann-Whitney $U$ diperoleh harga $U=0.000$ dan baris Asymp.Sig. (2-tailed) diperoleh nilai $=0.000<0,05$ maka dapat disimpulkan bahwa $\mathrm{H}_{\mathrm{a}}$ diterima. Dengan demikian dapat dikatakan bahwa ada perbedaan hasil belajar dengan motivasi rendah 


\section{JURNAL ILMIAH}

BINA EDUKASI

ISSN 1979-8598 E-ISSN: 2655-8378

http://journal.binadarma.ac.id/index.php/jurnalbinaedukasi

Vol. 14, No. 1, Juni 2021, 22 - 35

antara kelas ekperimen dan kelas kontrol. Dikarenakan perbedaan yang signifikan maka dapat menjawab hipotesis penulisan yaitu terdapat pengaruh hasil belajar mahasiswa yang memiliki motivasi belajar rendah yang diajarkan dengan menggunakan aplikasi Discord dan diajarkan dengan menggunakan aplikasi Whatsapp.

\subsubsection{Uji Spearman}

Pengujian menggunakan Uji Spearman menggunakan aplikasi SPSS 23.0 untuk mengetahui hubungan antara motivasi belajar dan hasil belajar mahasiswa pada penggunaan aplikasi Discord.

1. Jika nilai Signifikansi atau Asymp. Sig. (2-tailed) $>0.05 \mathrm{H}_{0}$ diterima.

2. Jika nilai Signifikansi atau Asymp. Sig. (2-tailed) $<0.05 \mathrm{H}_{0}$ ditolak.

Dari hasil perhitungan dengan menggunakan Uji Spearman berbantuan aplikasi SPSS 23.0 didapatkan output:

Tabel 7. Hasil Uji Spearman

\section{Correlations}

\begin{tabular}{|c|c|c|c|c|}
\hline \multirow{7}{*}{ Spearman's rho } & & & Motivasi Belajar & Hasil Belajar \\
\hline & \multirow[t]{3}{*}{ Motivasi Belajar } & Correlation Coefficient & 1.000 & $.973^{* *}$ \\
\hline & & Sig. (2-tailed) & & .000 \\
\hline & & $\mathrm{N}$ & 20 & 20 \\
\hline & \multirow[t]{3}{*}{ Hasil Belajar } & Correlation Coefficient & $.973^{* *}$ & 1.000 \\
\hline & & Sig. (2-tailed) & .000 & \\
\hline & & $\mathrm{N}$ & 20 & 20 \\
\hline
\end{tabular}

Berdasarkan output di atas, diketahui nilai signifikansi atau Sig. (2-tailed) sebesar 0,000, karena nilai Sig.(2- tailed) $0,000<0,05$ artinya ada hubungan yang signifikan antara variabel motivasi belajar dengan hasil belajar mahasiswa.

\subsection{Pembahasan}

Berdasarkan dari hasil kesimpulan perbandingan analisis data post-test hasil belajar mahasiswa kelas kontrol dan kelas eksperimen didapatkan skor tertinggi kelas eksperimen 95 dan skor terendah 75, sedangkan pada kelas kontrol di dapatkan skor tertinggi 75 dan skor terendah 45 dari hasil data tersebut dapat disimpulkan bahwa penggunaan aplikasi Discord pada pembelajaran daring sangat berpengaruh dilihat dari perbedaan nilai signifikan antara hasil nilai post-test kelas eksperimen dan kelas kontrol dan didukung oleh hasil analisis Uji Wilcoxon.

Berdasarkan hasil analisis data didapatkan nilai Mean Rank pada kelas eksperimen yang menggunakan aplikasi Discord sebesar 13.50 sedangkan nilai Mean Rank pada kelas kontrol yang menggunakan aplikasi Whatsapp sebesar 5.00, dengan demikian dapat disimpulkan bahwa pembelajaran dengan menggunakan Aplikasi Discord lebih baik dibandingkan dengan 


\section{JURNAL ILMIAH \\ BINA EDUKASI \\ ISSN 1979-8598 E-ISSN: 2655-8378 \\ http://journal.binadarma.ac.id/index.php/jurnalbinaedukasi \\ Vol. 14, No. 1, Juni 2021, 22 - 35}

pembelajaran menggunakan Aplikasi Whatsapp. Dengan demikian hipotesis penulisan kedua $\mathrm{H}_{\mathrm{a} 3}$ diterima dan hipotesis penulisan $\mathrm{H}_{03}$ ditolak.

Kedua hipotesis ini diterima karena terdapat pengaruh yang signifikan dibuktikan dengan adanya perbedaan rata-rata berkaitan perbedaan hasil belajar mahasiswa yang memiliki motivasi belajar tinggi dan hasil belajar mahasiswa yang memiliki motivasi belajar rendah yang diajarkan menggunakan aplikasi Discord dan diajar mengunakan aplikasi Whatsapp dapat diartikan bahwa pembelajaran dengan lingkup motivasi belajar lebih tinggi baik dari pembelajaran dengan lingkup motivasi belajar rendah.

Pada angka koefisien korelasi pada hasil di atas bernilai positif, yaitu 0.973, sehingga hubungan kedua variabel tersebut bersifat searah (jenis hubungan searah), dengan demikian dapat diartikan bahwa semakin ditingkatkan motivasi belajar maka hasil belajar juga akan meningkat. Dengan demikian hipotesis penulisan $\mathrm{H}_{04}$ : Tidak terdapat hubungan antara motivasi belajar dan hasil belajar mahasiswa pada penggunaan aplikasi Discord ditolak, dan $\mathrm{H}_{\mathrm{a} 4}$ : Terdapat hubungan antara motivasi belajar dan hasil belajar mahasiswa pada penggunaan Aplikasi Discord, diterima dikarenakan koefisien korelasi diperolah angka sebesar 0.973**. Artinya, tingkat kekuatan hubungan (korelasi) antara variabel motivasi belajar dengan hasil belajar sangat kuat.

\section{SIMPULAN}

Berdasarkan deskripsi hasil analisis data penulisan dan pembahasan yang telah dikemukakan pada bab sebelumnya, maka dapat diambil kesimpulan sebagai berikut.

1. Terdapat pengaruh yang signifikan terhadap hasil belajar mahasiswa yang menggunakan Aplikasi Discord lebih tinggi dari kelas yang menggunakan metode penugasan berbantuan Whatsapp. Hasil olah data ini diperkuat dengan Uji Wilcoxon pada baris Mean Rank peningkatan tersebut adalah sebesar 10.50, sedangkan jumlah rangking positif atau Sum of Ranks adalah sebesar 210.00.

2. Terdapat pengaruh yang signifikan dengan perbedaan hasil belajar mahasiswa yang memiliki motivasi belajar tinggi dan motivasi belajar rendah yang diajarkan menggunakan Aplikasi Discord dibuktikan dengan Uji Man-Whieney U didapatkan nilai Mean Ranks kelas eksperimen sebesar 17.38 dan nilai Mean Ranks kelas kontrol sebesar 6.14. Ini artinya penggunaan Aplikasi Discord tepat digunakan dalam pembelajaran daring.

3. Terdapat hubungan yang sangat kuat antara motivasi belajar mahasiswa dengan nilai hasil belajar mahasiswa pada penggunaan Aplikasi Discord yang didukung dengan hasil Uji Spearman Korelasi pada baris correlation coefficient sebesar $0.923 * *$. 


\section{DAFTAR PUSTAKA}

Absor, N. F. (2020). Pembelajaran Sejarah Abad 21: Tantangan dan Peluang dalam Menghadapi Pandemi Covid-19. Chronologia: Journal of History Education, 2(1). 30-35. doi:http://dx.doi.org/ 10.22236/jhe.v2i1.5502.

Budiyono. (2004). Statistika untuk Penulisan. Surakarta: Sebelas Maret University Press.

Citron ,J. (2020). "Helping out where we can" blog.Discord.com https://blog.Discord.com/helping-out-where-we-can-3a5fb7bac77a.

Creswell, J. W. (2012). Educational research plannig, conducting and evaluating quantitative and qualitative research. 4th edition. New York: Cambridge University Press.

Efriani, E., Dewantara, J. A., \& Afandi, A. (2020). PEMANFAATAN APLIKASI DISCORD SEBAGAI MEDIA PEMBELAJARAN ONLINE. Jurnal Teknologi Informasi Dan Pendidikan, 13(1). https://doi.org/10.24036/tip.v13i1.283.

Field, A. (2009). Discovering statistics using spss (3rd edition). London: SAGE Publication Ltd.

Kusnedi, Y St.(2020) "Implementasi Problem Based Learning Berbantuan Aplikasi Discord Sebagai Upaya Peningkatan Hasil Belajar Komputer Dan Jaringan Dasar Materi Sistem Operasi Pada Siswa Kelas X Tkj Smkn 2 Sampit”.

McKnight, P. E., \& Najab, J. (2010). Mann-Whitney U Test. The Corsini Encyclopedia of Psychology. doi:10.1002/9780470479216.corpsy0524

Raihan, J. P., \& Putri, Y. R. (2018). Pola komunikasi group Discord PUBG.INDO.FUN melalui aplikasi Discord. e-Proceeding of Management, 5(3), 4161-4169.

Sarwono, J \& Suhayati, E. (2010.) Riset Akuntansi Menggunakan SPSS. Edisi Pertama. Bandung: Graha Ilmu.

Sugiyono. (2016). Metode Penulisan Kuantitatif Kualitatif dan R\&D. Bandung: Alfabeta.

Sundayana, R. (2014). Statistika penulisan pendidikan. Bandung: Alfabeta.

Wulanjani, A. N. (2018). Discord Application: Turning a Voice Chat Application for Gamers into a Virtual Listening Class. In English Language and Literature International Conference (ELLiC) Proceedings (Vol. 2, pp. 115-119). 